KS. MAREK T. ZAHAJKIEWICZ - L.UBLIN

\title{
MIEJSCE BIBLIOTEK KOŚCIELNYCH W KULTURZE. WPROWADZENIE DO SYMPOZJUM
}

O bibliotekarzach mówi się zazwyczaj jako o działaczach kultury, a samą instytucję bibliotek wiąże się również z kulturą. To uzasadnia podjęcic przcz nas zagadnienia zawartego $\mathrm{w}$ tytule niniejszej wypowiedzi. W rozwinięciu tematu postaramy się $w$ formie skróconej naszkicować 3 elementy:

— czym jest kultura (jak ją definiujemy)?

- czym jest biblioteka (kościelna)?

- jaka jest wzajemna relacja miedzy kulturą a biblioteką?

Jednym z częściej używanych terminów w języku potocznym jest kultura. Jednak w tym wypadku jej rozumienie jest często jednoaspektowe i bardzo spłycone. Na przykład kulturę utożsamia się ze sposobem bycia, z grzecznością. Przez kulturę potocznie rozumie się czasem wyksztalcenie, czytelnictwo, uprawianie sportu, kino, teatr, zespoły artystyczne, ład moralny, atmosferę panującą w jakimś środowisku. Można by jeszcze mnożyć takie jednoaspektowe, a czasami spłycone pojmowanie tego terminu. Ponadto ostatnimi laty pewne kręgi ateistyczne słowo kultura wprost przeciwstawiają religii. Na skutek tego rodzi sic̨ konieczność dania odpowiedzi na pewne pytania. Pierwsze z nich dotyczy właściwego zdefiniowania pojęcia kultura. Kolejne $z$ nich dotyczy określenia miejsca w kulturze dla bibliotek. Przede wszystkim musimy uświadomić sobie, pomijając wyżej wskazane określenia, że w nauce istnieje sporo definicji kultury. Zaznaczmy od razu, że żadna $\mathrm{z}$ tych definicji nie uzyskała powszechnego uznania. Nie miejsce tutaj na analizowanie wszystkich, a nawet przynajmniej ważniejszych definicji. Jednak warto przytoczyć jedną definicję obszerniejszą i dla kontrastu jedną zwięzła, ale jak się wydaje mieszczące istotne elementy pojęcia kultury. W poszukiwaniu obszernej definicji kultury sięgnijmy do dokumentu magisterium Kościoła, a zawartego w jednym z rozdziałów Konstytucji duszpasterskiej o Kościele w świecie współczesnym (Gaudium et spes) Soboru Watykańskiego II. Należy 
sądzić, że cały ten rozdział' jest najbardziej zasadniczym opracowaniem na temat kultury w oficjalnych wypowiedziach Kościoła. Ponadto omówiono tutaj m.in. chrześcijańską teorię kultury, stosunek ogólnej kultury humanistycznej do kultury religijnej, oraz zaznaczono wkład Kościoła w osiagnięcia kultury ogólnoludzkiej. W tym dokumencie znajdujemy eklektyczną definicję kultury. Brzmi ona: „Mianem kultury w sensie ogólnym oznacza się wszystko, czym człowiek doskonali i rozwija wielorakie uzdolnienia swego ducha i ciała, stara się drogą poznania i pracy poddać sam świat pod swoją władzę; czyni bardziej ludzkim życie społeczne tak w rodzinie, jak i w całej społeczności państwowej przez postęp obyczajów i instytucji; wreszcie w dziełach swoich w ciagu wieków wyraża, przekazuje i zachowuje wielkie doświadczenia duchowe i dążenia na to, aby służyły one postępowi wielu, a nawet całej ludzkości"'. W powyższej definicji zawarte są takie elementy jak: doskonalenie człowieka, opanowanie świata przez poznanie i pracę, postęp w życiu, wreszcie zachowanie i przekaz tych doświadczeń służących całej ludzkości.

Ksiądz prof. Czesław Bartnik zastanawiając się nad tymi słowami napisał: „Kultura to uczłowieczenie życia. Jest to humanizacja i personalizacja bytu ludzkiego i świata. Jest to dążenie - z pewnymi skutkami - do amelioracji fenomenu ludzkiego oraz rzeczywistości w relacji do centrum osoby ludzkiej"3. Natomiast krótkie zdefiniowanie pojęcia kultury znajdujemy w Słowniku języka polskiego: „Kultura to całokształt materialnego i duchowego dorobku ludzkości gromadzony, utrwalany i wzbogacany w ciagu jej dziejów, przekazywany z pokolenia na pokolenie". W tym słowniku w dalszej kolejności jest określenie kultury ducha: „Kultura duchowa to ogół dzieł naukowych, literackich i dzieł sztuki tworzących dorobek ludzkości w danym okresie historycznym"4. W kontekście tego co wyżej powiedziano rodzi się pytanie o miejsce bibliotek kościelnych w kulturze? W Encyklopedii Katolickiej znajdujemy dość obszerne hasło poświęcone bibliotekom kościelnym ${ }^{5}$. Zaraz na jego wstępie podano w sensie szerszym definicję tego typu bibliotek, określając je jako: „utrzymywane przez państwo, związki lub instytucje społeczne dla kształcenia duchowienstwa i podnoszenia kultury religijnej w społeczeństwie". Zgodnie z tą definicją biblioteka kościelna jawi się więc jako instytucja włączająca się w szerzenie kultury. Jednak należałoby powyższą definicję nieco uzupełnić o szerzenie nie tylko kultury religijnej, ale również kultury szeroko pojętej. Bowiem biblioteki kościelne $w$ dawnych wiekach były jedynymi

${ }^{1}$ Konstytucja duszpasterska o Kościele w świecie wspólczesnym, Gaudium et spes, rozdz. 2, p. 53-62.

${ }^{2}$ Tamże, nr 53.

${ }^{3} \mathrm{Cz}$. B a r $\mathrm{n}$ i k, Kultura, w: In te Domine speravi. Ksiega pamiqtkowa poświęcona Księdzu Arcybiskupowi Bolestawowi Pylakowi Metropolicie Lubelskiemu, red. Cz. Bartnik, H. Langkamer, K. Góźdź, Lublin 1996, s. 24.

${ }^{4}$ Slownik języka polskiego, t. 1, Warszawa 1978, s. 1083.

${ }^{5}$ R. N i r, L. Grze b i e ń, Biblioteki kościelne, w: Encyklopedia Katolicka, t. 2, Lublin 1976, kol. 497-510. 
placówkami tego rodzaju, ale również aktualnie są uzupełnieniem sieci bibliotek państwowych. W tym ostatnim wypadku należy mieć na uwadze głównie biblioteki większe, np. uniwersytetów katolickich, czy innych katolickich zakładów naukowych $\mathrm{i}$ oświatowych gromadzących zbiory przekraczające ramy książki wyłącznie religijnej. Chociaż i dzisiaj w Polsce, kiedy zamyka się mniejsze biblioteki państwowe, biblioteka parafialna staje się uzupełnieniem sieci bibliotek ogólnopaństwowych. Tak więc biblioteki kościelne włączają się w kulturę szeroko pojęta, ale przede wszystkim mają swoje ulokowanie w działalności Kościoła -w jego misji.

Mówiąc o funkcjach i zadaniach bibliotek kościelnych warto skupić się nad trzema zagadnieniami:

1. Należy spojrzeć na nie jako na instytucje mające swoje miejsce zarówno w działalności duszpasterskiej Kościoła jak i w kulturze.

2. Musimy sobie uświadomić ich stan aktualny i wynikającą $\mathrm{z}$ tego troskę o ich uporządkowanie.

3. Będzie również pożyteczną rzeczą dostrzeżenie funkcjonowania bibliotek kościelnych na przestrzeni wieków.

Tak zostało uporządkowane spotkanie bibliotekarzy kościelnych mające miejsce w dniach 28-29 września 2004 roku. Mianowicie tak rozplanowano wszystkie wystąpienia prelegentów. 